\title{
Description of the third instar larvae of five species of Cyclocephala (Coleoptera, Melolonthidae, Dynastinae) from Mexico
}

\author{
Miguel A. Morón ${ }^{1}$, Gabriel A. Lugo-García² \& Agustín Aragón-García ${ }^{3}$
}

\begin{abstract}
${ }^{1}$ Red de Biodiversidad y Sistemática, Instituto de Ecología A. C., Apdo. Postal 63, Xalapa, Veracruz 91000, México. miguel.moron@inecol.mx 2 Escuela Superior de Agricultura del Valle del Fuerte, Universidad Autónoma de Sinaloa. Juan José Ríos, Ahome, Sinaloa 81110, México.

${ }^{3}$ Centro de Agroecología. Instituto de Ciencias, Benemérita Universidad Autónoma de Puebla. 14 sur 6301, Ciudad Universitaria, Puebla 72570, México.
\end{abstract}

\begin{abstract}
Description of the third instar larvae of five species of Cyclocephala (Coleoptera, Melolonthidae, Dynastinae) from Mexico. Larvae of four species of Cyclocephala are described for the first time based on specimens collected in Mexican localities: C. barrerai Martínez, 1969 from Puebla, C. sinaloae Howden \& Endrödi, 1966 from Sinaloa, C. fasciolata Bates, 1888 from Veracruz, and C. jalapensis Casey, 1915 from Hidalgo. Larva of C. lunulata Burmeister, 1847, is redescribed based on specimens from the Mexican states of Morelos, Puebla, and Veracruz. Diagnostic structures are illustrated and the differences and similarities of each species with other previously described larvae of the genus are commented.
\end{abstract}

KEYWORDS. Biology; immature; morphology; taxonomy; white grubs.

Despite their species richness, abundance and wide distribution along continental and insular Americas, the biology of the members of the genus Cyclocephala Dejan, 1821 is poorly known. This genus includes about 350 species (Ratcliffe et al. 2013), but only the larvae of 12 species have been described (Ritcher 1966; Morelli 1991; Morelli \& Alzugaray 1994; Bran et al. 2006; Lugo-García et al. 2009) (Table I). Adults fly predominantly during night hours. In temperate areas adults can be found on leaves or flowers of trees and shrubs, but in some species they do not feed (Ritcher 1966). In tropical humid areas the adults frequently feed inside the large inflorescences of Araceae (as Xanthosoma robustum Schott), on the flowers of Arecaceae (as Astrocaryum mexicanum Liebm. ex Mart.) or other epiphytic plants (Morón 1997, 1999). In subtropical less humid or semiarid areas adults are found on leaves of many shrubs or trees, including species of Acacia and Parkinsonia (Fabaceae) and Parthenium (Asteraceae) (Aragón-García et al. 2010). Occasionally, adults have been reported as injurious to orchards, chewing fruits of soft skin, as guava (Psidium guajava; Myrthaceae) (Aragón-García et al. 2012). Larvae live in the soil apparently feeding on humus, decomposed roots and stems, or eating live roots of cultivate grains or wild grasses and other herbs (Alzugaray et al. 1998; Lugo-García et al. 2009, 2012; Aragón-García et al. 2012).

The purpose of the present paper is to describe for the first time the third instar larva of Cyclocephala barrerai Martínez, 1969, C. sinaloae Howden \& Endrödi, 1966, C. fasciolata Bates, 1888 and C. jalapensis Casey, 1915, and redescribe the larva of $C$. lunulata Burmeister, 1847 based on various samples collected in Mexico, since previous de- scription of this species was based on samples from Colombia.

\section{MATERIAL AND METHODS}

Terms and characters used in the descriptions are those of Ritcher (1966) and Morón (1987). Drawings of diagnostic structures were made using a Leica stereomicroscope 0.8 $5.0 \mathrm{x}$ associated with a camera lucida, and measurements were obtained with an ocular micrometer (Leica microsystems, Germany). Voucher specimens were deposited at Centro de Agroecología, Benemérita Universidad Autónoma de Puebla (CENAGRO), Escuela Superior de Agricultura del Valle del Fuerte, Universidad Autónoma de Sinaloa (ESAVF) and Colección Entomológica Instituto de Ecología, A. C. Xalapa, México (IEXA).

\section{DESCRIPTIONS}

Larvae of Cyclocephala may be distinguished from other Dynastinae larvae by the following combination of characters: surface of cranium reticulate, weakly rugose or fairly smooth, light yellow to orange reddish brown. Stemmata present. Lateral margins of labrum rounded or weakly angulate posteriorly. Haptomeral process briefly notched forming two unequal teeth. Inner margin of mandible with or without tooth. Maxilla with a row of blunt truncate, stridulatory teeth. Last antennomere with two dorsal sensory spots. Raster with a teges formed by a variable number of hamate setae. Lower anal lip with hamate setae. Palidia absent. Two setae on each claw (Ritcher 1966; Morelli \& Alzugaray 1994). 
Table I. Known larvae of Cyclocephala. Updated species names in italics, names used in original description of larva in brackets.

\begin{tabular}{|c|c|c|c|}
\hline Species & Larva described from & References & Continental distribution of each species \\
\hline C. longula LeConte (C. abrupta Casey) & Oregon, USA & Ritcher (1966) & USA: AZ, CA, FL, NV, OR, TX, UT, WI. \\
\hline C. borealis Arrow & Kentucky and Connecticut, USA & Ritcher (1966) & $\begin{array}{l}\text { Canada: NS. USA: CA, CT, IL, IN, KS, KY, PA, TX. Mexico: } \\
\text { Dgo. }\end{array}$ \\
\hline $\begin{array}{l}\text { C. lurida Blandford (C. immaculata } \\
\text { auct.) }\end{array}$ & Kentucky, USA & Ritcher (1966) & $\begin{array}{l}\text { USA: AL, AR, AZ, CA, FL, IN, IL, KS, KY, LA, MO, MT, } \\
\text { NE, OK, PA, SC, TN, TX, VA. Mexico: Coah, Dgo, Hgo, NL, } \\
\text { Pue, Tamps, Ver. }\end{array}$ \\
\hline C. pasadenae Casey & California, USA & Ritcher (1966) & $\begin{array}{l}\text { USA: AZ, CA, CO, FL, IN, KS, NE, NM, PA, SC, TX, VA. } \\
\text { Mexico: Chih, Coah, Dgo, Son, Zac. }\end{array}$ \\
\hline C. signaticollis Burm. & Uruguay & Morelli (1991) & $\begin{array}{l}\text { Argentina: BA, CD, MN. Bolivia, Brazil: RS, SC, SP. } \\
\text { Uruguay. }\end{array}$ \\
\hline C. testacea Burm. & Uruguay & Morelli \& Alzugaray (1994) & $\begin{array}{l}\text { Argentina: CD, LR, MN, MZ, SA, TM. Colombia: ANT, } \\
\text { CAS, CUN. Bolivia, Brazil: AC, AM, ES, MT, PA, RJ, RS, } \\
\text { SC, SP. Ecuador, Guayana, Paraguay, Peru, Uruguay, } \\
\text { Venezuela: ARA. }\end{array}$ \\
\hline C. putrida Burm. & Uruguay & Morelli \& Alzugaray (1994) & $\begin{array}{l}\text { Argentina: BA, CD, CT, MZ, SA, SF, TM. Bolivia, Brazil: } \\
\text { GO, MG, MT, PR, RJ, RS, SC, SP. Guayana, Paraguay, } \\
\text { Uruguay, Venezuela: APU. }\end{array}$ \\
\hline C. modesta Burm. & Uruguay & Morelli \& Alzugaray (1994) & $\begin{array}{l}\text { Argentina: BA, CD, CT, MN, MZ, ST, TM. Bolivia, Brazil: } \\
\text { BA, ES, MT, PA, RS, SC, SP. Paraguay, Uruguay. }\end{array}$ \\
\hline C. fulgurata Burm. & Antioquia, Colombia & Bran et al. (2006) & $\begin{array}{l}\text { Mexico: Chis, Ver. Central America, Argentina: BA. } \\
\text { Colombia: ANT, CAU, CUN, CHO, TOL, VAC. Bolivia, } \\
\text { Ecuador, Guayana, Peru, Venezuela: CAR, DC, MER, MON. }\end{array}$ \\
\hline C. lunulata Burm. & $\begin{array}{l}\text { Caldas, Colombia, Valle del Cauca, } \\
\text { Colombia, Morelos, Puebla, Veracruz, } \\
\text { Mexico }\end{array}$ & $\begin{array}{l}\text { Bran et al. (2006), } \\
\text { Stechauner-Rohringer \& } \\
\text { Pardo-Locarno (2010), } \\
\text { Present paper }\end{array}$ & $\begin{array}{l}\text { Mexico: Ags, Chis, Col, Gro, Hgo, Jal, Mex, Mich, Mor, Nay, } \\
\text { Oax, Pue, QR, Sin, SLP, Tamps, Ver, Yuc. Central America, } \\
\text { Colombia: ANT, BOL, BOY, CAU, CUN, MET, NAR, SAN, } \\
\text { TOL, VAC. Venezuela: ARA, DC, MER, MON. Trinidad, } \\
\text { Guayana, Ecuador, Peru, Brasil: BA, ES, GO, MG, PR, RJ, } \\
\text { RS, SC, SP. Bolivia, Paraguay, Argentina: BA, TM. }\end{array}$ \\
\hline C. gregaria H.et T. & Antioquia, Colombia & Bran et al. (2006) & $\begin{array}{l}\text { Panamá, Bolivia, Brasil: SP. Colombia: ANT, BOY, CAU, } \\
\text { CUN, MAG, QUI, SAN, TOL, VAC, Ecuador, Venezuela: } \\
\text { MER. }\end{array}$ \\
\hline C. comata Bates & Jalisco, Mexico & Lugo-García et al. (2009) & Mexico: Dgo, Jal, Mex, Mich, Oax. \\
\hline C. barrerai Martínez & Puebla, Mexico & Present paper & Mexico: DF, Dgo, Mex, Pue, Tlax. \\
\hline C. sinaloa H.et E. & Sinaloa, Mexico & Present paper & Mexico: Jal, Sin. \\
\hline C. fasciolata Bates & Veracruz, Mexico & Present paper & $\begin{array}{l}\text { Mexico: Chis, Pue, Ver. Guatemala, Costa Rica, Panama. } \\
\text { Colombia: ANT. }\end{array}$ \\
\hline C. jalapensis Casey & Hidalgo, Mexico & Present paper & Mexico: Hgo, Oax, Pue, Ver. \\
\hline
\end{tabular}

\section{Cyclocephala barrerai Martínez, 1969}

(Figs. 1-12)

Description. Head (Fig. 1). Maximum width of head capsule: 4.0-4.2 mm. Surface of cranium rugose, orange yellowish. Frons without exterior frontal setae, with 2 posterior frontal setae, 1 anterior frontal seta, 1 anterior angle seta, 2-3 dorsoepicranial, 3 epicranial setae on each side and 5-7 setae behind each antennal support. Clypeus without central seta, with 1 lateral seta on each side. Labrum symmetrical with rounded lateral margins, 3-4 posterior setae, 1-2 central setae and 1-2 lateral setae on each side. Stemmata present. Epipharynx (Fig. 2) $1.3-1.6 \mathrm{~mm}$ width, $1.2-1.5 \mathrm{~mm}$ length, epizygum and zygum fused as irregular, elongate, dark reddish brown plate. Raised haptomerum weakly notched; plegmatia and proplegmatia absent. Each acanthoparia with 7-8 spine-like setae. Dexiophoba and laeophoba absent. Dexiotorma narrowed, elongate nearly straight. Laeotorma elongate and narrowed. Haptolachus absent. Sclerotized plate long and narrowed. Crepis absent. Left chaetoparia with 34-39 spine-like and stout setae mixed. Right chaetoparia with 36-41 long and stout setae. Mandibles (Figs. 3-4) with ventral stridulatory area; scissorial area in both mandibles with sharp distal blade. Right mandible with 1 small tooth on inner margin, and distal lobe (M1) of molar area well developed; brustia scarcely setose.
Left mandible with distal lobe weakly developed, inner margin simply curved. Calx prominent, brustia with few setae. Maxillae (Figs. 5, 8). Mala with 1 uncus on apex of galea, 2 fused unci surrounded by 7-9 stout heli on apex of lacinia; stridulatory area with 8-10 small teeth. Hypopharyngeal sclerome (Fig. 9) asymmetrical with prominent right side. Last antennomere with 2-3 ovate, dorsal sensory spots (Fig. 6) and 2-3 ventral sensory spots (Fig. 7).

Thorax. Respiratory plates light yellow, uniformly curved, "C" shaped (Fig. 11) 0.18-0.30 mm length, 0.12-0.16 mm width, bulla rounded, distance between lobes less than dorsoventral diameter of bulla. Lateral sclerome of pronotum elongate, light yellow, with slender long setae. Pro-prescutum with 10-11 long setae regularly distributed; pro-scutum with 5-6 slender long setae; meso-prescutum with transverse row of 6-7 long setae; meso-scutum without setae; meso-scutellum with row of 5-6 slender long setae; meta-prescutum with transverse row of 3-4 mixed short and long setae; metascutum without setae; meta-scutellum with transverse row of 9-10 mixed short and long setae. Pro- and meso-tarsal claws long, sharply pointed, with 1 pre-basal inner seta and 1 lateral external seta (Fig. 10); meta-tarsal claw sharply pointed but shorter than preceding ones.

Abdomen. Respiratory plates light yellow, regularly curved, "C" shaped; on segments I-VI with similar diam- 

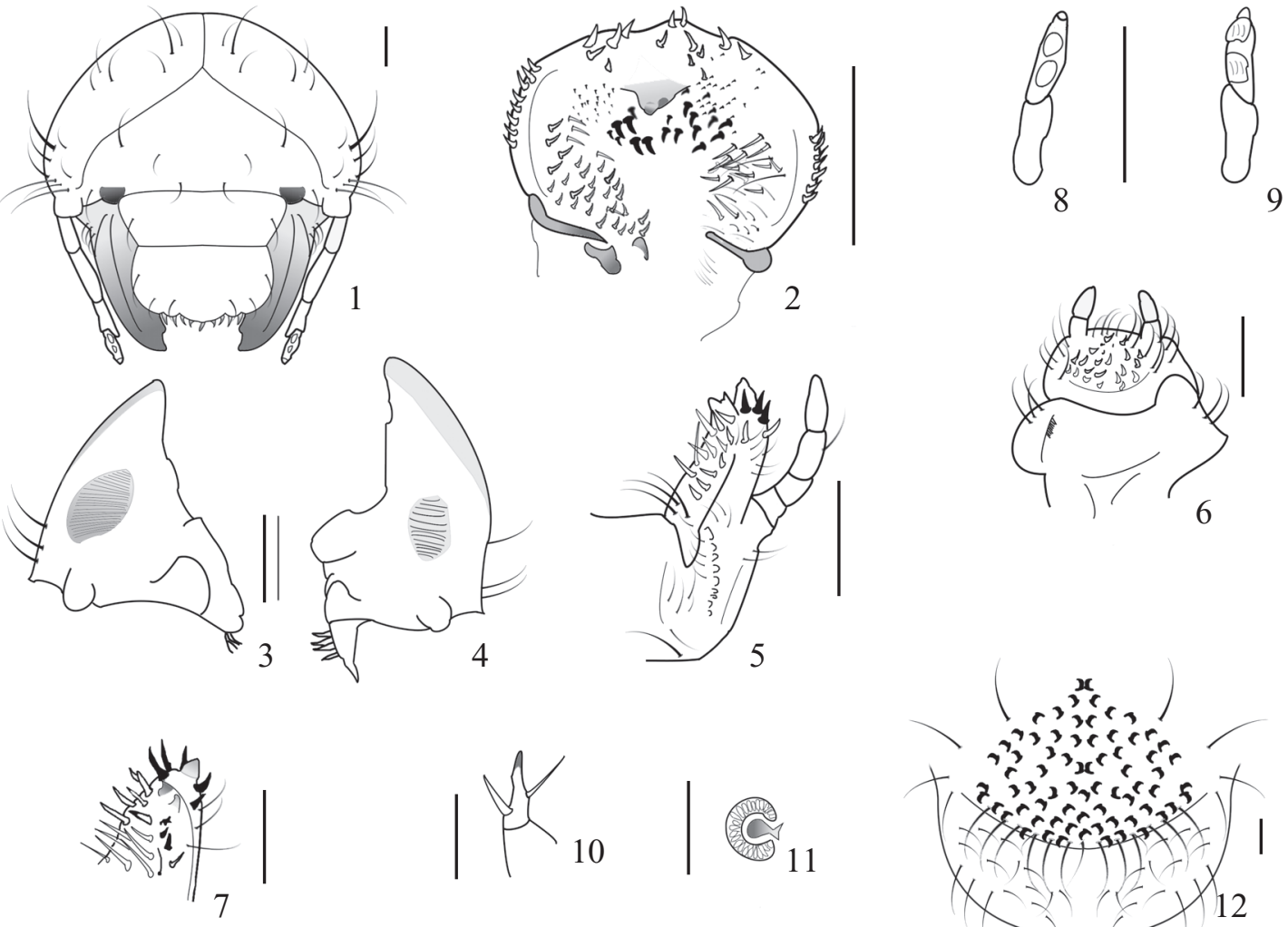

Figs. 1-12. Third instar of Cyclocephala barrerai. 1, Head, frontal view. 2, Epipharynx. Mandibles, ventral view: 3, left. 4, right. 5, Right maxilla, dorsal view. Last antennomere: 6, dorsal. 7, ventral. 8, Apex right maxilla, mesal view. 9, Labium and hypopharynx. 10, Protarsal claw. 11, Prothoracic respiratory plate. 12, Raster. Scales $1 \mathrm{~mm}$, except Figs. 6, 7, 10-11 $=0.5 \mathrm{~mm}$.

eter, $0.18-0.27 \mathrm{~mm}$ length, $0.12-0.16 \mathrm{~mm}$ width; plates on segments VII-VIII are slightly larger, $0.20-0.30 \mathrm{~mm}$ length, $0.14-0.18 \mathrm{~mm}$ width. Dorsa of abdominal segments I-VII each with numerous spine-like short setae and transverse row of few long setae; dorsa of segments VIII-IX with transverse rows of 11-13 slender, long setae. Venter of abdominal segments I-VII with transverse rows of 9-11 slender, long setae; venter of segments VIII-IX with transverse rows of 3-5 mixed short and long setae. Raster (Fig. 12) without palidia; tegilla with 43-46 short, stout hamate setae with curved tips; campus with 4-6 slender, long setae; barbula moderately setose. Dorsal anal lip with 16-18 stout, short hamate setae. Ventral anal lip with 30-32 stout, short setae with curved tips. Anal slit nearly transverse. Mean dorsal body length $24 \mathrm{~mm}(2.2-3.4 \mathrm{~mm})$.

Studied specimens. Four third instar larvae collected directly under golf grass mixture at Mexico: Puebla: Puebla municipality, Club de Golf La Vista, 28-VIII-2007, G. A. Lugo-García col. (IEXA). Nine third instars, same data except: 12-III-2009, A. Aragón-García (CENAGRO).

Comments. The larva of $C$. barrerai resembles those of C. longula and C. sinaloae, but does not have any exterior frontal seta, and the clypeus lacks central setae, while the other species have 2 exterior frontal setae and 2 central setae on the clypeus; $C$. longula bears 7-8 dorso epicraneal setae on each side, while $C$. barrerai bears only $2-3$ setae on each side. The number and distribution of hammate setae on the raster is much different in all three cited species, the tegilla of $C$. barrerai being formed by 43-46 setae, while in $C$. sinaloae and $C$. longula it is formed by 29-33 setae; the lower anal lip of C. sinaloae has 59-62 hammate setae, while in $C$. barrerai it has 30-32 setae, and in C. longula, 22 setae.

Biology. Cyclocephala barrerai is distributed in the Mexican states of Aguascalientes, Chihuahua, Durango, Jalisco, Morelos, Puebla and in Distrito Federal, between 1500-2500 $\mathrm{m}$ of elevation. Larvae have been collected frequently under roots of diverse grass species and sometimes under maize. Adults are attracted to electric lights during summer, but their host plants are unknown (Morón et al. 2013).

\section{Cyclocephala sinaloae Howden \& Endrödi, 1966}

(Figs. 13-24)

Description. Head (Fig. 13). Maximum width of head capsule: 4.7-4.9 mm. Surface of cranium smooth, orange yellowish. Frons with 1exterior frontal setae, 2 posterior frontal seta, 3 anterior frontal setae, 1 anterior angle seta, 3-4 dorso-epicranial, 3 epicranial setae on each side and 7-8 setae behind each antennal support. Clypeus with 2 central seta, and 1-2 lateral seta on each side. Labrum symmetrical with rounded lateral margins, 5-6 posterior setae, 2 central setae and 2-3 lateral setae on each side. Stemmata present. Epiphar- 

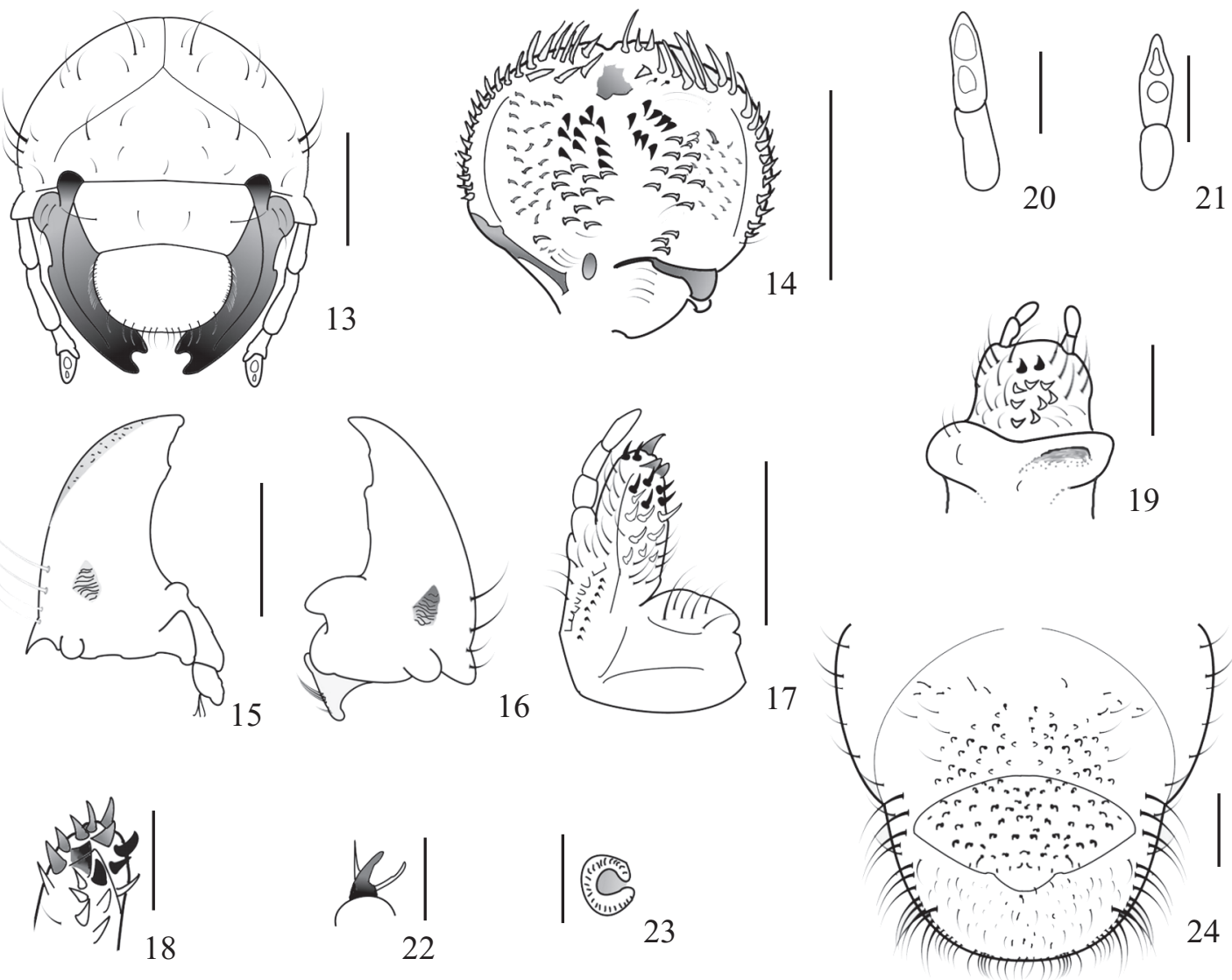

Figs. 13-24. Third instar of Cyclocephala sinaloae. 13, Head, frontal view. 14, Epipharynx. Mandibles, ventral view: 15, left. 16, right. 17, Right maxilla, dorsal view. Last antennomere: 18, dorsal. 19, ventral. 20, Apex, right maxilla, mesal view. 21, Labium and hypopharynx. 22, Protarsal claw. 23, Prothoracic respiratory plate. 24, Raster. Scales $1 \mathrm{~mm}$, except Figs. 18-19, 22-23=0.5 mm.

ynx (Fig. 14) 1.7-1.9 mm width, 1.5-1.7 mm length, epizygum and zygum fused as irregular, elongate, dark reddish brown plate. Raised haptomerum weakly notched; plegmatia and proplegmatia absent. Each acanthoparia with 12-13 spine-like setae. Dexiophoba and laeophoba absent. Dexiotorma narrowed, elongate nearly straight. Laeotorma elongate and narrowed. Haptolachus absent. Sclerotized plate small, ovate. Crepis absent. Left chaetoparia with 33-37 spine-like and stout setae mixed. Right chaetoparia with 3840 stout, short setae. Mandibles (Figs. 15-16) with ventral stridulatory area; scissorial area in both mandibles with sharp distal blade, clearly separate from proximal small scissorial tooth by scissorial notch. Left mandible with small tooth on inner margin, and distal lobe (M1) of molar area well developed; brustia scarcely setose. Right mandible with distal lobe of molar area weakly developed, inner margin without tooth. Calx prominent, brustia moderately abundant. Maxillae (Figs. 17, 20). Mala with 1 uncus on apex of galea, 2 unci surrounded by 7-9 stout heli on apex of lacinia; stridulatory area with 7 small teeth. Hypopharyngeal sclerome (Fig. 21) asymmetrical, lobed, with prominent right side. Last antennomere with 2 ovate, dorsal sensory spots (Fig. 18) and 2 ventral sensory spots (Fig. 19).

Thorax. Respiratory plates light yellow, uniformly curved,
"C" shaped (Fig. 23) 0.21-0.26 mm length, 0.18-0.23 mm width, bulla rounded, distance between lobes less than dorsoventral diameter of bulla. Lateral sclerome of pronotum elongate, light yellow, with slender long setae. Pro-prescutum with 6-8 mixed short and long setae regularly distributed; pro-scutum with 6-7 mixed short and long setae irregularly distributed; meso-prescutum with transverse row of 5-7 mixed medium size and long setae; meso-scutum with 5-6 short setae; meso-scutellum without setae; meta-prescutum with transverse row of 5-6 mixed short and long setae; metascutum with 5-6 mixed short and long setae; meta-scutellum without setae. Pro- and meso-tarsal claws long, sharply pointed, with 1 pre-basal inner seta and 1 lateral external seta (Fig. 22); meta-tarsal claw sharply pointed but shorter and narrower than preceding ones.

Abdomen. Respiratory plates light yellow, regularly curved, "C" shaped; on segments I-VI with similar diameter, 0.21-0.24 mm length, 0.19-0.23 mm width; plates on segments VII-VIII are slightly larger, $0.22-0.26 \mathrm{~mm}$ length, $0.20-0.24 \mathrm{~mm}$ width. Dorsa of abdominal segments I-VII each with numerous spine-like short setae, and transverse row of few long setae; dorsa of segments VIII-IX with few transverse rows of 8-10 slender, long setae, and scattered short, spine-like setae. Venter of abdominal segments I-VII 
with transverse rows of 8-10 mixed short and long setae; venter of segments VIII-IX with transverse rows of 2-4 mixed medium size and long setae. Raster (Fig. 24) without palidia; tegilla with 29-33 short, compressed, stout hamate setae with curved tips; campus with 7-8 slender, long setae; barbula moderately setose. Dorsal anal lip with 45-46 short hamate setae and many long setae. Ventral anal lip with 59-62 stout, short setae. Anal slit nearly transverse. Mean dorsal body length $36.2 \mathrm{~mm}(2.7-4.2 \mathrm{~mm})$.

Studied specimens. Seventy-two third instar larvae collected directly from soil in maize culture at Mexico: Sinaloa, Ahome municipality, Revolución Mexicana, 36 m osl, 12-XI-2008, G. A. Lugo-García col. (IEXA, CENAGRO, ESAVF).

Comments. The larva of $C$. sinaloae resembles that of $C$. borealis and $C$. lurida, but has a small tooth on the inner border of left mandible, while the other species have such border slightly curved; $C$. sinaloae and $C$. lurida have the respiratory plate on abdominal segment I as large as the plates on segments II-VI, and the plates on segments VII-VIII are larger than those on preceding segments, while in C. borealis the plate on segment $\mathrm{I}$ is as large as the plates on segments VII-VIII, and the plates on segments II-VI are smaller than the others. Also, the number of hammate setae on the raster is different, in C. sinaloae the lower anal lip has 59-62 setae, while such lip in C. borealis it has 20 setae and in C. lurida, 35 setae.

Biology. Cyclocephala sinaloae is distributed in the Mexican states of Sinaloa and Jalisco, below $1300 \mathrm{~m}$ of elevation. Larvae are abundant under roots of maize and other wild grasses. Adults mate on twigs of Acacia farnesiana (L.) Willd. and Parkinsonia aculeata L., feed on leaves of diverse plants such as Parthenium argentatum A. Gray, and sometimes on the fruits of Psidium guajava L.; they are attracted to electric lights during July and August (Aragón et al. 2010; LugoGarcía et al. 2012).

\section{Cyclocephala lunulata Burmeister, 1847}

(Figs. 25-36)

Description. Head (Fig. 25). Maximum width of head capsule: $4.6-5.0 \mathrm{~mm}$. Surface of cranium slightly rugose, orange yellowish. Frons with 1 exterior frontal setae, 2 posterior frontal seta, 2 anterior frontal setae, 1 anterior angle seta, 2-3 dorso-epicranial, 1 epicranial seta on each side and 8 setae behind each antennal support. Clypeus with 2 central setae, and 1 lateral seta on each side. Labrum symmetrical with rounded lateral margins, 15-16 posterior setae, 2 central setae and 3 lateral setae on each side. Stemmata present. Epipharynx (Fig. 26) 1.5-1.8 mm width, 2.0-2.2 mm length, without zygum but with irregular, wide, dark brown epizygum. Raised haptomerum weakly notched; plegmatia and proplegmatia absent. Each acanthoparia with 8-15 curved, spine-like setae. Dexiophoba irregular; laeophoba absent. Dexiotorma irregular, elongate. Laeotorma narrowed. Haptolachus with scattered microsensilla. Sclerotized plate large, ovate. Crepis absent. Left chaetoparia with 33-35 spinelike, stout setae, and 17-19 slender setae. Right chaetoparia with 31-33 stout setae and 17-19 slender setae. Mandibles (Figs. 27-28) with ventral stridulatory area; scissorial area in both mandibles with sharp distal blade, clearly separate from proximal small scissorial tooth by scissorial notch. Left mandible without tooth on inner margin, and distal lobe (M1) of molar area well developed; brustia scarcely setose. Right mandible with distal lobe of molar area weakly developed, inner margin simply curved. Calx prominent, brustia dense. Maxillae (Figs. 29, 32). Mala with 1 uncus on apex of galea, 3 unci fused surrounded by 3-4 stout heli on apex of lacinia; stridulatory area with 8 small teeth. Hypopharyngeal sclerome (Fig. 33) asymmetrical, lobed, with prominent right side. Last antennomere with 2 ovate, dorsal sensory spots (Fig. 30) and 2 ventral sensory spots (Fig. 31).

Thorax. Respiratory plates light yellow, uniformly curved, "C" shaped (Fig. 35) 0.39-0.42 mm length, 0.32-0.37 mm width, bulla rounded, distance between lobes less than dorsoventral diameter of bulla. Lateral sclerome of pronotum irregularly elongate, light yellow, with 4 slender long setae. Pro-prescutum with 2 long setae towards each side; proscutum with 8 mixed short and long setae on irregular transverse row; meso-prescutum with transverse row of 6 medium size setae; meso-scutum with 8 long setae; meso-scutellum without setae; meta-prescutum with transverse row of 6 mixed short and long setae; meta-scutum with 6 mixed short and long setae; meta-scutellum without setae. Pro- and meso-tarsal claws long, sharply pointed, with 1 pre-basal inner seta and 1 lateral external seta (Fig. 34); meta-tarsal claw sharply pointed but shorter and narrower than preceding ones.

Abdomen. Respiratory plates light yellow, regularly curved, "C" shaped; on segments I-VI with similar diameter, 0.33-0.35 mm length, 0.23-0.24 mm width; plate on segment VII $0.39-0.40 \mathrm{~mm}$ length, $0.37-0.38 \mathrm{~mm}$ width; plate on segment VIII $0.44-0.45 \mathrm{~mm}$ length, $0.39-0.40 \mathrm{~mm}$ width. Dorsum of abdominal segment I with mixture of few spine-like short setae and slender long setae; dorsa of segments II-VI each with numerous spine-like short setae, and transverse row of few long setae; dorsa of segments VII-IX without spine-like setae and few transverse rows of 4-12 slender, long setae. Venter of abdominal segments I-IX with transverse rows of 4-6 medium size setae. Raster (Fig. 36) without palidia; tegilla with 28-32 short, compressed, stout hamate setae with curved tips; campus with 2-4 slender, long setae; barbula moderately setose. Dorsal anal lip with 28-30 short spine-like setae and few, scattered long setae. Ventral anal lip with 26-30 stout, curved setae. Anal slit weakly curved. Mean dorsal body length $40 \mathrm{~mm}$ (38-42 $\mathrm{mm})$.

Studied specimens. Four third instar larvae collected directly from soil in sugar cane culture at Mexico: Morelos, Yautepec, San Carlos, 16XI-1978, M. A. Morón col. (IEXA). Four third instar larvae collected from soil in peanut culture at Morelos, Atlacahualoya, 7-VII-1981, 1,050 m osl, G. Avalos col. (IEXA). Three third instar larvae and 1 exuvium collected from soil in maize culture at Morelos, Tlaltizapan, Pueblo Nuevo, 31-III-1989, C. Deloya col. (IEXA). Five third instar larvae collected from 

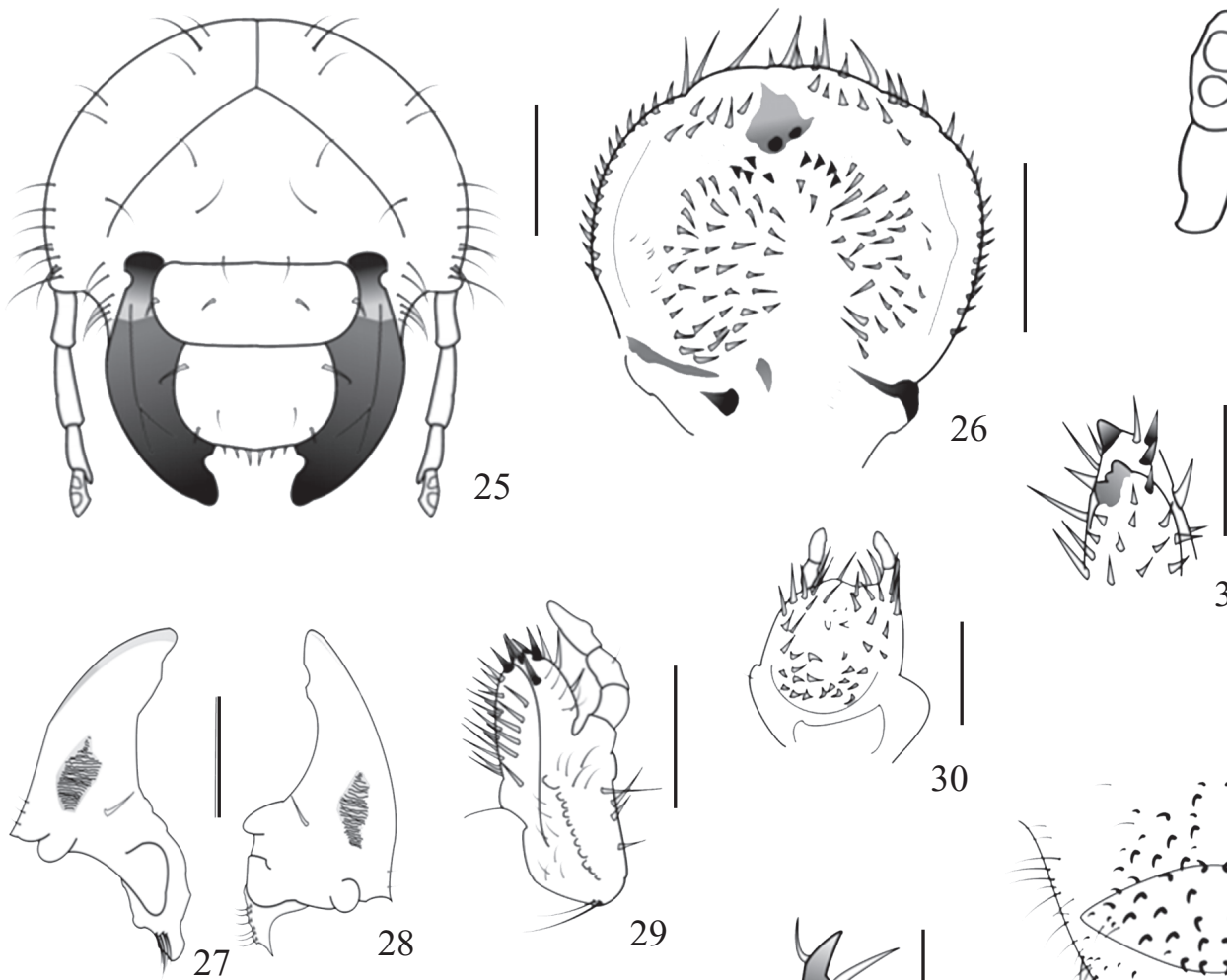

29

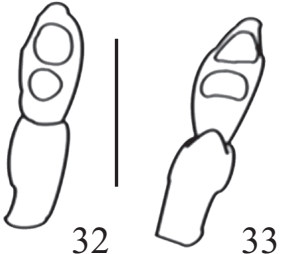

31
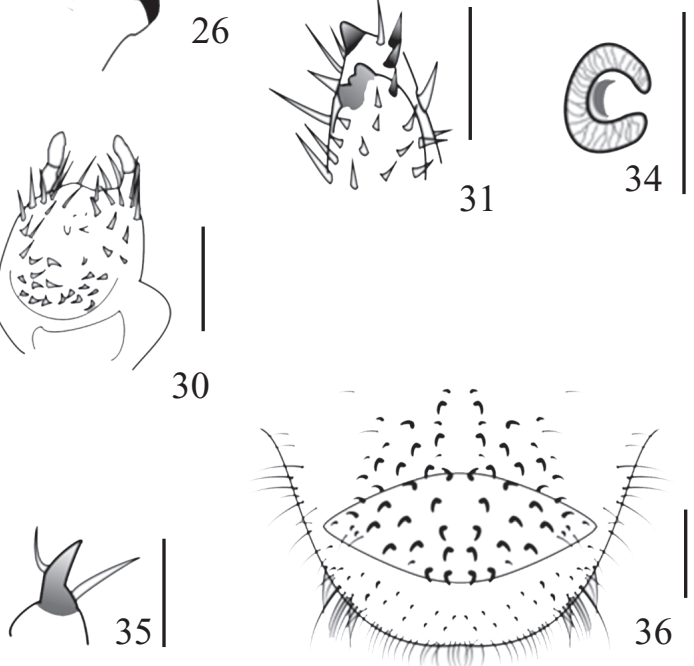

Figs. 25-36. Third instar of Cyclocephala lunulata. 25, Head, frontal view. 26, Epipharynx. Mandibles, ventral view: 27, left. 28, right. 29, Right maxilla, dorsal view. Last antennomere: 30, dorsal. 31, ventral. 32, Apex, right maxilla, mesal view. 33, Labium and hypopharynx. 34, Protarsal claw. 35, Prothoracic respiratory plate. 36, Raster. Scales $1 \mathrm{~mm}$, except Figs. 30-31, 34-35 $=0.5 \mathrm{~mm}$.

soil in culture of statice flower (Limonium sinuatum) at Puebla, Atlixco, Rancho La Joya, 21-X-1998, J. Michimani col. (IEXA). Two third instar exuviae collected from soil in tropical pasture land at Veracruz: San Andrés Tuxtla, colonia Ruiz Cortines, 23-II-1985, M. L. Castillo col. (IEXA).

Comments. The larva of $C$. lunulata may be separated from all other described larvae of the genus because the respiratory plates of their segments VI-VIII are clearly larger than preceding plates, as well the diameter of plates VI-VIII are progressively enlarged. It differs from larvae of $C$. barrerai and $C$. sinaloae for lacking the tooth on inner border of left mandible, and bearing few spine-like setae on the dorsum of first abdominal segment. Specimens from Mexican localities have a few differences compared to specimens described from Colombia by Bran et al. (2006) and StechaunerRohringer \& Pardo-Locarno (2010): lack of exterior frontal setae, presence of 8 stridulatory teeth, tegilla with 28-32 hammate setae, ventral anal lip with 26-30 setae, and head capsule width of 4.6-5.0 mm. The Colombian specimens have 1-2 exterior frontal setae, 7 stridulatory teeth, tegilla with 20-36 hammate setae, ventral anal lip with 29-34 setae, and head capsule width of $4.2-4.5 \mathrm{~mm}$.

Biology. Cyclocephala lunulata is widely distributed in nearly all Mexican states, except Chihuahua, Coahuila, Durango, Campeche, Zacatecas, and Baja California peninsula, and extends it distribution to Central and South America.
Larvae have been collected under live or rotten roots of sugarcane, maize, peanuts, alfalfa, dry-land rice, cultures of flowers of Limonium (Plumbaginaceae), and wild grasses, as well as in soils rich in organic matter. Adults feed on fruits of corn, guava, sugar apple (Annona), mango, fig and peach; they are frequently attracted to electric lights all year long. Apparently one-year life cycle is common in dry regions, but the species is bivoltine in wet localities (Aragón \& Morón 2000; Aragón-García et al. 1998; Stechauner-Rohringer \& Pardo-Locarno 2010).

\section{Cyclocephala fasciolata Bates, 1888}

(Figs. 37-48)

Description. Head (Fig. 37). Maximum width of head capsule: $4.0-4.1 \mathrm{~mm}$. Surface of cranium slightly rugose, dark yellow. Frons without exterior frontal setae and anterior frontal setae, with 1-2 posterior frontal setae, 1 anterior angle seta, 3 dorso-epicranial, 2 epicranial setae on each side and 2-3 setae behind each antennal support. Clypeus with 2 central setae and 1 lateral seta on each side. Labrum symmetrical with rounded lateral margins, without posterior setae, 2 central setae and 3 lateral setae on each side. Stemmata present, but small. Epipharynx (Fig. 38) 1.9-2.0 mm width, 1.6-1.7 mm length, without zygum but with weak irregular 

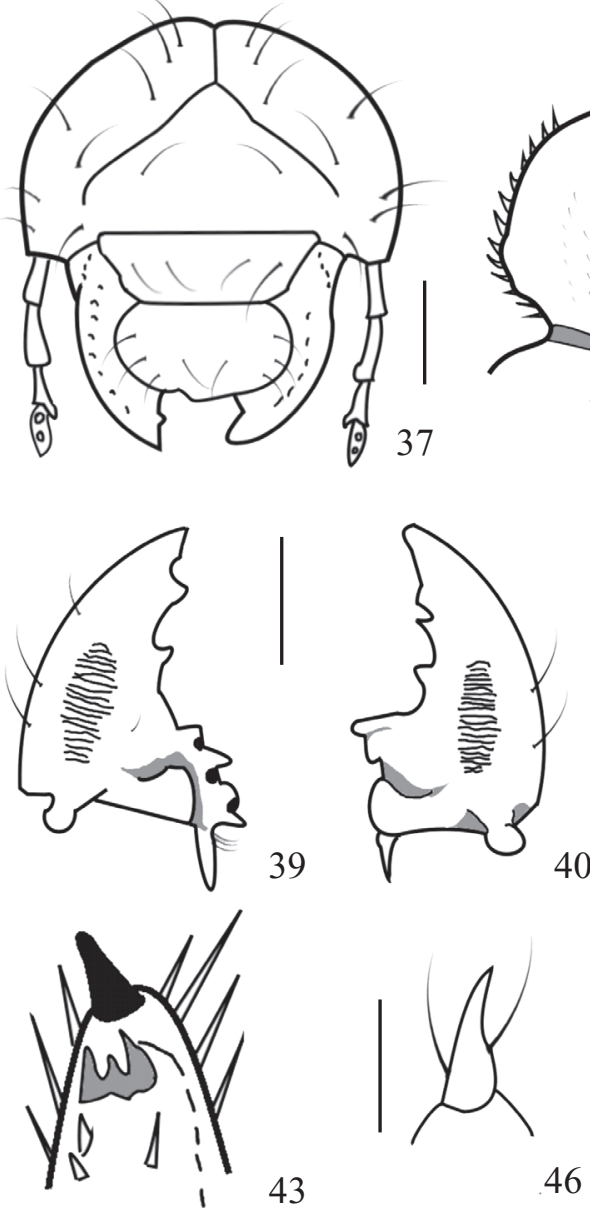

46

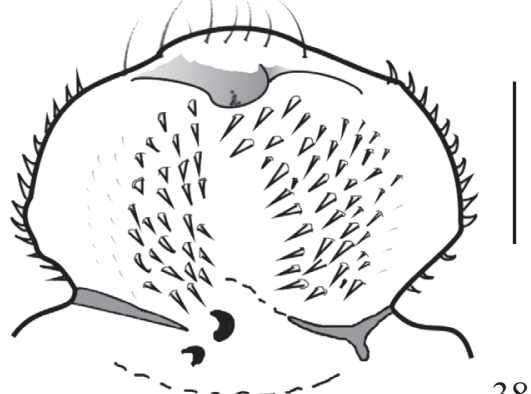

38
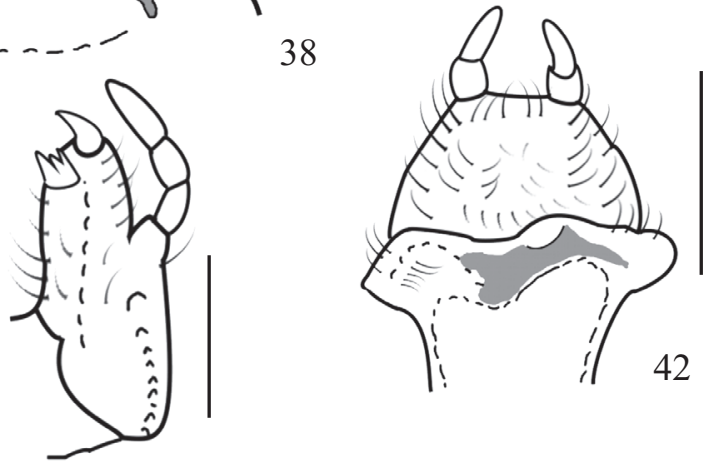

41
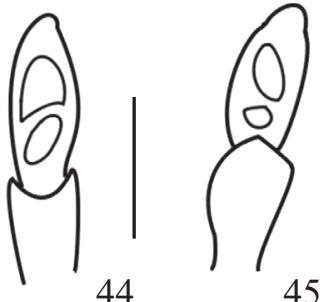

45

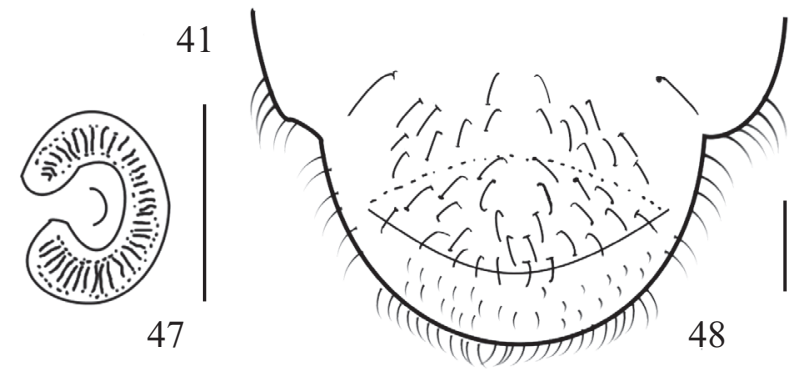

Figs. 37-48. Third instar of Cyclocephala fasciolata. 37, Head, frontal view. 38, Epipharynx. Mandibles, ventral view: 39, left. 40, right. 41, Right maxilla, dorsal view. Last antennomere: 42, dorsal. 43, ventral. 44, Apex, right maxilla, mesal view. 45, Labium and hypopharynx. 46, Protarsal claw. 47, Prothoracic respiratory plate. 48, Raster. Scales $1 \mathrm{~mm}$, except Figs. 42-43, 46-47 = $0.5 \mathrm{~mm}$.

dark epizygum. Raised haptomerum weakly notched; plegmatia and proplegmatia absent. Each acanthoparia with 9-10 curved, spine-like setae on distal half and 3 short setae on proximal half. Dexiophoba scarce; laeophoba absent. Dexiotorma elongate, straight. Laeotorma narrowed with small pternotorma. Haptolachus with few microsensilla. Sclerotized plate small, sense cone prominent. Crepis weakly defined. Left chaetoparia with 27-30 stout setae towards pedium, and 10-12 spine-like setae towards border. Right chaetoparia with 24-26 stout setae and 15-17 spine-like setae. Mandibles (Figs. 39-40) with ventral stridulatory area; scissorial area in both mandibles with sharp distal blade, clearly separate from proximal small scissorial tooth by wide scissorial notch. Left mandible with 2 acute teeth on inner margin, and distal lobe (M1) of molar area well developed; brustia scarcely setose. Right mandible with distal lobe of molar area weakly developed, inner margin with 1 acute tooth. Calx elongate, brustia scarce. Maxillae (Figs. 41-42). Mala with 1 uncus on apex of galea, 3 unci of different length basally fused surrounded by $4-5$ stout heli on apex of lacinia; stridulatory area with 8 small teeth. Hypopharyngeal sclerome (Fig.43) asymmetrical, lobed, with prominent right side. Last antennomere with 2 irregular and ovate, dorsal sensory spots (Fig. 44) and 2 ventral sensory spots with different shape and size (Fig. 45).

Thorax. Respiratory plates light yellow, uniformly curved, "C" shaped (Fig. 46) $0.43 \mathrm{~mm}$ length, $0.31 \mathrm{~mm}$ width, bulla rounded, distance between lobes less than dorso-ventral diameter of bulla. Each lateral sclerome of pronotum irregularly elongate, light yellow, with 2 short slender short setae and 1 long seta. Pro-prescutum with 4 short setae regularly distributed; pro-scutum with 8 long setae regularly distributed; mesoprescutum with transverse row of 8 long setae; meso-scutum with 6 long setae; meso-scutellum without setae; metaprescutum with transverse row of 8 long setae; meta-scutum with 6 long setae; meta-scutellum without setae. Pro- and mesotarsal claws long, sharply pointed, with 1 pre-basal inner seta and 1 lateral external seta (Fig. 47); meta-tarsal claw sharply pointed but shorter and narrower than preceding ones.

Abdomen. Respiratory plates light yellow, regularly curved, "C" shaped; plate on segment I with $0.40 \mathrm{~mm}$ length, 0.25 $\mathrm{mm}$ width, plates on segments II-VI with similar diameter, $0.58 \mathrm{~mm}$ length, $0.30 \mathrm{~mm}$ width; plate on segment VII 0.55 $\mathrm{mm}$ length, $0.42 \mathrm{~mm}$ width; plate on segment VIII $0.45 \mathrm{~mm}$ 
length, $0.34 \mathrm{~mm}$ width. Dorsa of abdominal segments I-II each with mixture of scarce medium size and long setae; dorsa of segments III-VII each with mixture of many medium size and long setae; segment VIII with scattered long setae; segments IX-X with few long setae. Venter of abdominal segments IVIII each with transverse row of 4 medium size setae; venter of segment IX with few scattered long setae. Raster (Fig. 48) without palidia; tegilla with 16 , slender setae; campus with 2 slender, long setae; barbula scarcely setose. Dorsal anal lip with 26-28 short spine-like setae and few, scattered long setae. Ventral anal lip with 26-28 stout, curved setae. Anal slit curved. Approximate dorsal body length $36 \mathrm{~mm}$.

Studied specimens: Three third instar exuviae collected under rotten log at Mexico: Veracruz, Los Tuxtlas, UNAM Biological Station, 10-VIII1986, 140 m, M. L. Castillo col. One third instar exuvium collected in soil (0-5 cm deep) same data except 3-X-1986 (IEXA).

Comments. The larva of $C$. fasciolata may be separated from other known larvae of the genus because it has 1 tooth on inner border of right mandible and 2 teeth on same border of left mandible, and respiratory plates of segments VI-VIII are progressively smaller than the plate of fifth segment. Also, the dorsa of abdominal segments do not have spine-like short setae. Head chaetotaxy is more similar to C. jalapensis, without exterior and anterior frontal setae, 2-4 posterior frontal setae, and 3 dorso-epicraneal setae. Also, the abundance of hammate setae on raster is similar to C. jalapensis, with tegilla formed by 16 setae, and lower anal lip with 26-28 setae.

Biology. Larvae collected under rotten logs in tropical rain forest during August 1986 pupated at the end of December of the same year. Adults emerged after 24-29 days. This species have been recorded from southeastern Mexico to Colombia. Adults fly from April to October, but are rarely attracted by electric lights. In localities of the state of Veracruz, Mexico, both sexes visit the inflorescences of Astrocaryum mexicanum Liebm. ex Mart. (Arecaceae) during April and the large inflorescences of Monstera deliciosa Liebm. and Philodendron sp. (Araceae) during July (Morón 1997, 2004).

\section{Cyclocephala jalapensis Casey, 1915}

$$
\text { (Figs. 49-58) }
$$

Description. Head (Fig. 49). Maximum width of head capsule: $4.0 \mathrm{~mm}$. Surface of cranium slightly rugo-punctate, dark yellow. Frons without exterior frontal setae and anterior frontal setae, with 1 posterior frontal seta, 1 anterior angle seta, 3 dorso-epicranial, 2 epicranial setae on each side and 2-3 setae behind each antennal support. Clypeus with 2 central setae and 1 lateral seta on each side. Labrum nearly symmetrical with rounded lateral margins, without posterior setae, 2 central setae and 3 lateral setae on each side. Stemmata present, but small. Epipharynx (Fig. 50) $1.9 \mathrm{~mm}$ width, $1.7 \mathrm{~mm}$ length, without zygum but with weak irregular epizygum. Raised haptomerum weakly notched; plegmatia and proplegmatia absent. Each acanthoparia with 9 curved, spine-like setae on distal half and 3 short setae on proximal half. Dexiophoba and laeophoba absent. Dexiotorma elongate, nearly straight. Laeotorma elongate with wide pternotorma. Haptolachus with few microsensilla. Sclerotized plate large, sense cone prominent. Crepis weakly defined. Left chaetoparia with 32 stout setae towards pedium, and 16 spine-like setae towards border. Right chaetoparia with 34 stout setae and 14 spine-like setae. Mandibles (Figs. 51-52) with ventral stridulatory area; scissorial area in both mandibles with sharp distal blade, clearly separate from proximal small scissorial tooth by wide scissorial notch. Left mandible with 1 acute tooth on inner margin, and distal lobe (M1) of molar area well developed; brustia scarcely setose. Rigth mandible with distal lobe of molar area weakly developed, inner margin without tooth. Calx short, brustia scarce. Maxillae (Figs. 53-54). Mala with 1 uncus on apex of galea, 3 unci of different length basally fused surrounded by 4 stout heli on apex of lacinia; stridulatory area with 5-6 small teeth. Hypopharyngeal sclerome (Fig. 54) asymmetrical, lobed, with prominent right side. Last antennomere with 2 irregular, ovate, dorsal sensory spots (Fig. 56) and 2 ventral sensory spots with different size (Fig. 57).

Thorax. Respiratory plates light yellow, uniformly curved, "C" shaped, $0.40 \mathrm{~mm}$ length, $0.25 \mathrm{~mm}$ width, bulla rounded, distance between lobes less than dorso-ventral diameter of bulla. Each lateral sclerome of pronotum irregularly elongate, light yellow, with 1 long setae. Pro-prescutum with 4 long setae regularly distributed; pro-scutum with 6 long setae irregularly distributed; meso-prescutum with transverse row of 6 long setae; meso-scutum with 6 long setae; mesoscutellum without setae; meta-prescutum with transverse row of 6 long setae; meta-scutum with 6 long setae; meta-scutellum without setae. Pro- and meso-tarsal claws long, sharply pointed, with 1 pre-basal inner seta and 1 lateral external seta; meta-tarsal claw sharply pointed but shorter and narrower than preceding ones.

Abdomen. Respiratory plates light yellow, regularly curved, "C" shaped; plates on segments I-VI with diameter, $0.30 \mathrm{~mm}$ length, $0.21 \mathrm{~mm}$ width; plate on segment VII 0.35 $\mathrm{mm}$ length, $0.25 \mathrm{~mm}$ width; plate on segment VIII $0.35 \mathrm{~mm}$ length, $0.30 \mathrm{~mm}$ width. Dorsum of abdominal segment I with mixture of few short spine-like setae and slender long setae; dorsa of segments II-VI each with numerous spine-like short setae, and transverse row of few long setae; dorsum of segment VII with few spine-like setae and row of 6 long setae; dorsa of segments VIII-IX each without spine-like setae, but with 6 long setae; segment $X$ with scattered slender long setae. Venter of abdominal segments I-IX with transverse rows of 2 short and 4 long setae. Raster (Fig. 58) without palidia; tegilla with 16 slender setae; campus with 2 slender, long setae; barbula scarcely setose. Dorsal anal lip with 28 short spine-like setae and scattered long setae. Ventral anal lip with 26 slender, curved setae. Anal slit curved. Approximate dorsal body length $32 \mathrm{~mm}$.

Studied specimens. One third instar exuvium collected under forest litter at Mexico: Hidalgo, Zacualtipán, Tepeoco, 1800 m, 18-XII-1979, M. A. Morón col. One third instar exuvium with same data except: camino a Zoyatla, 4-XI-1978 (IEXA). 

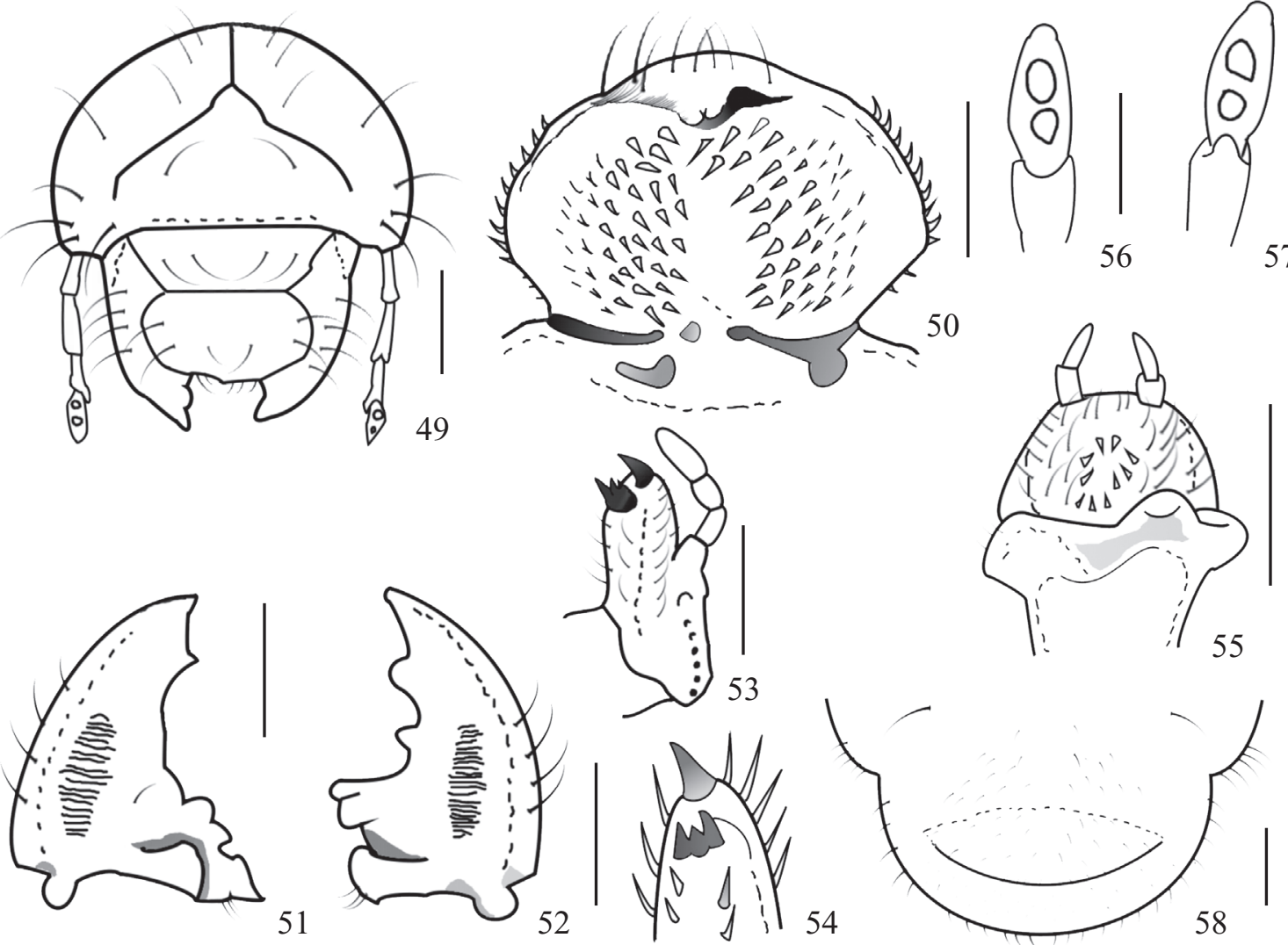

55

Figs. 49-60. Third instar of Cyclocephala jalapensis. 49, Head, frontal view. 50, Epipharynx. Mandibles, ventral view: 51, left. 52, right. 53, Right maxilla, dorsal view. 54, Apex, right maxilla, mesal view. 55, Labium and hypopharynx. Last antennomere: 56, dorsal. 57, ventral. 58, Raster. Scales 1 $\mathrm{mm}$, except Figs. 54-55, 56-57 $=0.5 \mathrm{~mm}$

Comments. Larva of $C$. jalapensis looks much similar to that of $C$. fasciolata but presents scarce short, spine-like setae on the dorsa of the abdominal segments. Also, it has 1 tooth on the inner border of left mandible and the same border of right mandible simply curved. Stridulatory organ of maxilla is formed by $5-6$ teeth, instead of 8 teeth as in $C$. fasciolata. Respiratory plates of abdominal segments VIIVIII are longer than the preceding ones.

Biology. Larva collected under leaf litter of oak and sweet gum forest during November 1978 pupated in April 20, 1979, and the adult emerged May 5 of same year. Dorsally, the abdomen of the pupa have six pairs of dioneiform organs, proximal pair completely formed, next four pairs moderately defined, and distal pair weakly defined. This species have been recorded only in eastern Mexico (Hidalgo, Puebla, Oaxaca, Queretaro, Veracruz). Adults fly from May to August, are easily attracted to electric lights, and feed in the great flowers of Magnolia schideana Schldt. (Magnoliaceae) (Morón 1977; Dieringer \& Delgado 1994).

\section{ACKNOWLEDGMENTS}

The aid of César V. Rojas, Roberto Arce (INECOL) and Miguel Aragón Sánchez (BUAP) during technical and field works is here recognized. This paper was supported in part by the research line "Coleópteros Lamelicornios de América Latina" Instituto de Ecología, A.C. Xalapa (account 2004010011).

\section{REFERENCES}

Alzugaray, R., Ribeiro, A., Zerbino, A. M., Morelli, E. \& Castiglioni, E. 1998. Evaluación de los insectos del suelo en Uruguay, p.151-164. In: Morón, M.A. \& Aragón, A. (eds.). Avances en el estudio de la diversidad, importancia y manejo de los coleópteros edafícolas americanos. Puebla, Publicación Especial Benemérita Universidad Autónoma de Puebla y Sociedad Mexicana de Entomología, 184 p.

Aragón, A. \& Morón, M.A. 2000. Los coleópteros Melolonthidae asociados a la rizosfera de la caña de azúcar en Chietla, Puebla. Folia Entomológica Mexicana 108: 79-94.

Aragón-García, A., Lugo-García, G.A., Reyes-Olivas, A., Casillas-Álvarez, P., Villegas-Cota, J.R. \& Morón, M.A. 2010. Huéspedes vegetales de adultos de Coleoptera Scarabaeoidea en el Valle del Carrizo, Sinaloa, México. Southwestern Entomologist 35: 99-108.

Aragón-García, A., Morón, M.A., Tapia-Rojas, A.M. \& Rojas-García, R. 1998. Las especies de Coleoptera Melolonthidae relacionadas con plantas cultivadas en el estado de Puebla, México, p. 131-142. In: Morón, M.A. \& Aragón, A. (eds.). Avances en el estudio de la diversidad, importancia y manejo de los coleópteros edafícolas americanos. Puebla, Publicación Especial Benemérita Universidad Autónoma de Puebla y Sociedad Mexicana de Entomología, 184 p.

Aragón-García, A., Morón, M.A., Damián-Huato, M.A., López-Olguín, J.F., Pinsón-Rincón, E.P. \& Pérez-Quintanilla, J.N. 2012. Fauna de Coleoptera Lamellicornia de la zona cañera del ingenio de Atencingo, Puebla, México. Acta Zoológica Mexicana (n.s.) 28: 161-171. 
Bran, A.M., Londoño, M.E. \& Pardo, L.C. 2006. Morfología de estados inmaduros de tres especies de Cyclocephala (Coleoptera: Melolonthidae) con una clave para larvas de tercer estado en Colombia. Revista Corpoica - Ciencia y Tecnología Agropecuaria 7: 58-66.

Dieringer, G. \& Delgado, L. 1994. Notes on the biology of Cyclocephala jalapensis (Coleoptera: Scarabaeidae) an endemic of eastern Mexico. Southwestern Entomologist 19: 309-311.

Lugo-García, G., Ortega-Arenas, L., González-Hernández, H., AragónGarcía, A., Romero-Nápoles, J. \& Cortés, R.R. 2009. Descripción de las larvas de tercer instar de Melolonthidae (Coleoptera) asociadas al cultivo de Agave tequilana var. azul y su fluctuación poblacional en Jalisco, México. Neotropical Entomology 38: 769-780.

Lugo-García, G. A., Ortega-Arenas, L.D., Aragón-García, A., GonzálezHernández, H., Romero-Nápoles, J., Reyes-Olivas, A. \& Morón, M.A. 2012. Especies de gallina ciega (Coleoptera: Scarabaeoidea) asociadas al cultivo del maíz en Ahome, Sinaloa, México. Agrociencia 46: 307-320.

Morelli, E. 1991. Descripción de la larva y la pupa de Cyclocephala signaticollis Burmeister, 1847 (Coleoptera: Dynastinae) y observaciones sobre su biologia. Elytron supplement 5: 189-195.

Morelli, E. \& Alzugaray, R. 1994. Descripción de la larva de Cyclocephala testacea Burmeister, 1847 y clave para la determinación de cuatro especies del género Cyclocephala en el Uruguay (Coleoptera, Dynastinae). Revista Brasileira de Biologia 54: 77-84.

Morón, M.A. 1977. Redescripción de Cyclocephala jalapensis Casey (Coleoptera: Melolonthidae: Dynastinae). Folia Entomológica Mexicana 38: 19-28.

Morón, M.A. 1987. Los estados inmaduros de Dynastes hyllus Chevrolat
(Coleoptera: Melolonthidae, Dynastinae) con observaciones sobre su biología y el crecimiento alométrico del imago. Folia Entomológica Mexicana 72: 33-74.

Morón, M.A. 1997. Melolonthidae y Scarabaeidae, p. 227-243. In: González-Soriano, E., Dirzo, R. \& Vogt, R.C. (eds.). Historia Natural de Los Tuxtlas. México, UNAM y CONABIO, 647 p.

Morón, M.A. 1999. Notas sobre Cyclocephala Latreille (Coleoptera: Melolonthidae: Dynastinae) asociadas con Xanthosoma Schott (Araceae) en Chiapas, México. Giornale Italiano di Entomologia 8: 399-407.

Morón, M.A. 2004. Escarabajos. 200 millones de años de evolución. Zaragoza, Instituto de Ecología, A. C. y Sociedad Entomológica Aragonesa, 204 p.

Morón, M.A., Aragón-García, A. \& Carrillo-Ruiz, H. (eds.) 2013. Fauna de escarabajos del estado de Puebla. Publicado por M. A. Morón. Coatepec, Veracruz, México, 467 p.

Ratcliffe, B.C., Cave, R.D. \& Cano, E.B. 2013. The Dynastine scarab beetles of Mexico, Guatemala and Belize (Coleoptera: Scarabaeidae: Dynastinae). Bulletin of the University of Nebraska State Museum 27: $1-666$.

Ritcher, P.O. 1966. White grubs and their allies. A study of North American Scarabaeoid larvae. Corvallis, Oregon State University Press, 219 p.

Stechauner-Rohringer, R. \& Pardo-Locarno, L.C. 2010. Redescripción de inmaduros, ciclo de vida, distribución e importancia agrícola de Cyclocephala lunulata Burmeister (Coleoptera: Melolonthidae: Dynastinae) en Colombia. Boletín Científico. Centro de Museos, Museo de Historia Natural 14: 203-220.
Received 25 February 2014; accepted 16 July 2014

Associate Editor: Marcela L. Monné 